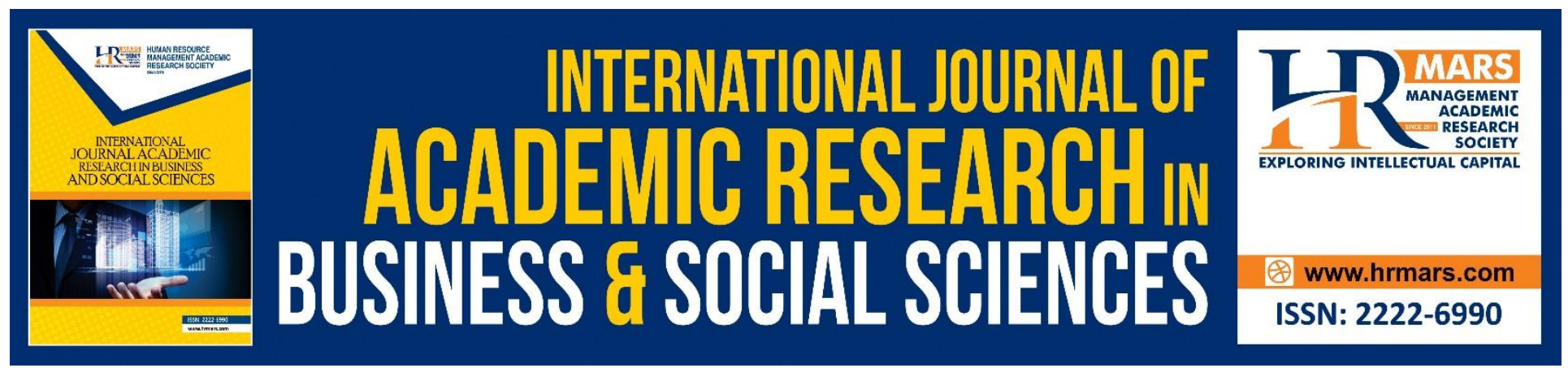

\title{
Examining the Relationship between Political Connections, Related Party Transactions, and Firm Value in Egyptian Listed Companies: Empirical Study
}

\author{
Hala Abdel-Naby Abdel-Fattah, Nesma Ahmed El-Shayeb, Hagar Essam \\ Sayed Ahmed Ameria
}

To Link this Article: http://dx.doi.org/10.6007/IJARBSS/v10-i9/7768

DOI:10.6007/IJARBSS/v10-i9/7768

Received: 11 June 2020, Revised: 15 July 2020, Accepted: 11 August 2020

Published Online: 28 September 2020

In-Text Citation: (Abdel-Fattah, El-Shayeb, \& America, 2020)

To Cite this Article: Abdel-Fattah, H. A-N., El-Shayeb, N. A., \& America, H. E. S. A. (2020). Examining the Relationship between Political Connections, Related Party Transactions, and Firm Value in Egyptian Listed Companies: Empirical Study. International Journal of Academic Research in Business and Social Sciences. 10(9), 393-413.

Copyright: (c) 2020 The Author(s)

Published by Human Resource Management Academic Research Society (www.hrmars.com)

This article is published under the Creative Commons Attribution (CC BY 4.0) license. Anyone may reproduce, distribute, translate and create derivative works of this article (for both commercial and non-commercial purposes), subject to full attribution to the original publication and authors. The full terms of this license may be seen

at: http://creativecommons.org/licences/by/4.0/legalcode

Vol. 10, No. 9, 2020, Pg. $393-413$

http://hrmars.com/index.php/pages/detail/IJARBSS

JOURNAL HOMEPAGE

Full Terms \& Conditions of access and use can be found at http://hrmars.com/index.php/pages/detail/publication-ethics 


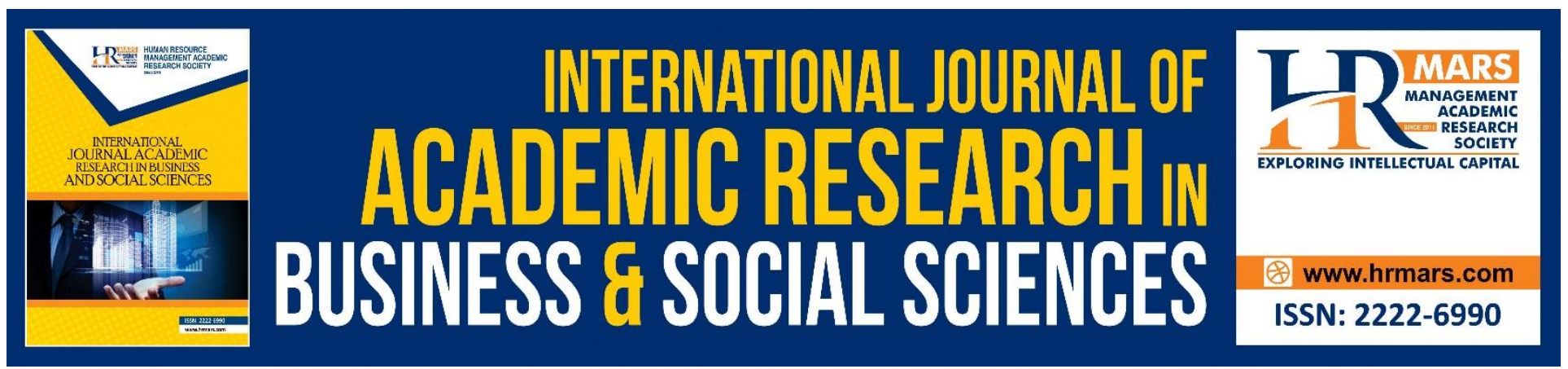

\title{
Examining the Relationship between Political Connections, Related Party Transactions, and Firm Value in Egyptian Listed Companies: Empirical Study
}

\author{
Hala Abdel-Naby Abdel-Fattah, Nesma Ahmed El-Shayeb, Hagar \\ Essam Sayed Ahmed Ameria
}

Accounting Department, Faculty of Commerce, Cairo University, Cairo, Egypt

Email: hagar_essam@foc.cu.edu.eg

\begin{abstract}
The main objective of the current research is to examine the effect of political connections and related party transactions on firm value. Moreover, the moderating role of related party transactions on the relationship between political connections and firm value is investigated. The research sample covers a period of five years from 2014 to 2018, including 33 Egyptian firms listed in the Egyptian Stock Exchange, resulted in 165 firm-year observations. The results show that: first, there is a significant positive relationship between political connections and firm value measured by Tobin's $Q$. Second, there is a significant positive relationship between related party transactions related to assets including investments with associates and due from related parties and firm value. Third, related party transactions do not moderate the relationship between political connections and firm value as all interaction variables are insignificant.
\end{abstract}

Keywords: Political Connections, Related Party Transactions,Firm Value.

\section{Introduction}

The well-known Arab revolutions, also called the "Arab Spring revolutions" have played a vital role in increasing the people's awareness in the Middle East. These revolutions have caused the downfall of huge political entities, subsequently, resulting in the downfall of economic entities associated with them as the economic and political systems are linked.

The political connections phenomenon has attracted academic research (Yang et al., 2012; Chen et al, 2017). Political connections may be beneficial for firms especially in developing countries because of their inferior institutional systems, more concentrated ownership structures, and less efficient legal systems (Schweizer et al., 2017).

The issue of politically connected firms has continuously been debated. Some academic researchers believed that political connections can improve firm value. By contrast, other researchers believed that political connections may reduce firm value. Explaining the impact of political connections on 
INTERNATIONAL JOURNAL OF ACADEMIC RESEARCH IN BUSINESS AND SOCIAL SCIENCES Vol. 10, No. 9, 2020, E-ISSN: 2222-6990 @ 2020 HRMARS

the firm value depends on the outlook on the effect (whether helping hands or grabbing hands) (Chen et al., 2017).

It is found that political connections can help firms to gain benefits such as easier access to debt financing, more tax avoidance, market power, and lighter regulatory oversight (Chen et al., 2017). Political connections phenomenon is a double-edged weapon as, politically connected firms have low accounting information quality (Chaney et al., 2011), low foreign investments, poor accounting performance (Boubakri et al., 2008), and weak corporate governance (Habib et al., 2017).

Although studies on the relative benefits and shortcomings of political connections have grown over time, the instruments used by connected firms to expropriate minority wealth remain

mysterious. Some studies argued that firms with political connections might utilize related party transactions (RPTs). RPTs can allow firms with political connections to structure transactions among their affiliates, e.g., tunneling, propping, or earnings management (Habib et al., 2017).

After the several financial crises that occurred over the last few decades such as Enron (2001), WorldCom (2002), and Tyco (2002), RPTs disclosures have become one of the most important topics. They received attention in both political discussions and media (Srinivasan, 2013; Tsai et al., 2015). Two main types of RPTs may help to explain why previous empirical researches about RPTs and firm value are inconsistent: efficient RPTs and abusive RPTs. Efficient RPTs rationally meet the economic needs of a company, reduce transaction costs, and facilitate the enforcement of property rights and essential contracts for the company (Bona-Sánchez et al., 2017). Thus, in less developed markets where transaction costs are high, RPTs will improve efficiency, facilitate long-term relations and reduce firms' risks through money reallocation and income cash flow transfer from one partner to another when needed (Tambunan et al., 2017).

On the other hand, abusive RPTs are used as the device that allows the controlling shareholders to expropriate the non-controlling shareholders by transferring the corporate resources to maximize their wealth through self-deal transactions. This type of transactions will make the transparency of the financial statements is in doubt as this type will increase the earnings management, reduce firm performance, increase the audit fees, increase the abnormal stock returns and all of this will reduce the firm value (Bona-Sánchez et al., 2017; Elkelis, 2017).

The results of previous studies contradicted with each other due to using different theories to investigate these relationships, conducting the research in different environments and different regulatory settings, and using different proxies. Thus, the current research aims to examine the relationship between political connections, RPTs, and firm value in the context of Egypt to enhance firm value and help investors to make the right decisions.

This research belongs to the literature that looks at the intersection between politics, accounting, and finance. It contributes to the literature in several important ways. First, it adds to the growing literature on the effect of political connections on firm value by adding new evidence from firms in a developing country. In doing so, this research will contribute to the literature by applying the analysis on the Egyptian stock market, as the majority of studies were conducted in China and other developed countries.

Second, the breaking down of RPTs into two types helps to investigate the effect of different types of transactions on firm value in Egypt. Third, while most studies have indicated that RPTs have an impact on firm value, to the best of the researcher's knowledge, little attention has been directed to address the effects of RPTs and their types on the relationship between political connections and firm market value in Egypt. 
INTERNATIONAL JOURNAL OF ACADEMIC RESEARCH IN BUSINESS AND SOCIAL SCIENCES Vol. 10, No. 9, 2020, E-ISSN: 2222-6990 @ 2020 HRMARS

This research is organized as follows; section 2 presents literature review and hypotheses development. Section 3 clarifies the empirical tests including the sample selection procedures, measurement of variables, and results of regressions. Finally, the last section presents the conclusions of the research.

\section{Literature Review and Hypotheses Development}

\section{Political Connections and Firm Value}

The issue of politically connected firms has continuously been debated. Some academic researchers believed that political connections can improve firm value. While the other believed that political connections may reduce firm value. Explaining the impact of political connections on the firm value depends on the outlook on the effect (whether helping hands or grabbing hands) (Chen et al., 2017). It was clear from the previous studies that there was relationship between political connections and firm value or firm performance but there was a debate on the direction of the relationship whether it was positive or negative. The contradicting results of the previous studies have been most likely caused by many reasons;

First, there were two competing theories concerning the effect of political connections on the value of firms. Some argued that political connections provide a "helping hand" to improve firm value by facilitating the acquisition of scarce resources and providing protection especially in weak institutional settings (Do et al., 2015; Green and Homroy, 2016; Wang et al., 2018; Shin et al., 2018). However, others argued that political connections can act as a "grabbing hand" as politicians had their agendas that may not be consistent with wealth maximization; thus, political connections may force firms to presume excess corporate social responsibility, and less likely to access international financing, which then eventually harm the firm value (Faccio, 2006; Chen et al., 2017; Liu et al., 2018; Shi et al., 2018).

Second, the settings of countries in which the research has been performed. Therefore, the previous results could not be generalized because these studies have been applied in different environments and different regulatory settings. For example, there were several studies in china because, political networks in China are very important for business firms and this importance arises from the state control of scarce resources such as subsidies, bank loans, land, and tax breaks, and government officials' firm site visits occur regularly in China as it is a familiar practice for government officials to visit companies (Wang, 2015; Wang, 2016; Liu et al.,2018; Chen et al.,2017; Wang et al.,2018; Shi et al.,2018).

Korea has been investigated in this area because the high level of corruption and family business groups "chaebols" are ubiquitous in Korea. Choi (2014) found that connected chaebol firms had a stock return that was $4.98 \%$ higher than other firms and these results consistent with the valueadding hypothesis. Shin et al., (2018) investigated the performance of politically connected directors in Korean chaebol firms and concluded that there was a positive relationship.

Moreover, Chung et al. (2019) examined whether the changes in the political environment in the Korean market could affect the value of firms measured by Tobin's $Q$ or not. It was found that there was a positive relationship between political ties and firm valuation as the political ties to the regime in power provide more benefits to connected firms than non-connected firms. On the other hand, political ties to the rival regime had negative effects on connected firms.

Do et al. (2015) suggested a significant positive impact of social-network on firm value in the US. The value connected firms to governors increased by $1.36 \%$. The study of Green and Homroy (2016) found 
INTERNATIONAL JOURNAL OF ACADEMIC RESEARCH IN BUSINESS AND SOCIAL SCIENCES Vol. 10, No. 9, 2020, E-ISSN: 2222-6990 @ 2020 HRMARS

that firms in the UK with members of parliament on the board have positive abnormal returns around the event, while firms with ex-members had no changes in firm value at the same time.

The literature in the Middle East area included investigations of how autocrats permit business leaders to control and monopolize the business sector to support their regime by creating more jobs or financing the election campaigns. In Egypt, scholars noted that political connections bloomed from 2004 to 2011 (Diwan et al., 2015).

Diwan et al. (2015) used a sample of 469 politically connected companies in Egypt to examine the economic effects of close state-business ties. The results revealed that politically connected firms receive benefits such as energy subsidies, trade protection, and easy access to land and all of these benefits lead to higher profits. Furthermore, it was found that the profitability of politically connected firms is two times than non-connected firms between 2005 and 2010.

Acemoglu et al. (2017) used the political turmoil in Egypt from 2011-2013 to investigate the effect of street protests on the returns of politically connected firms with the National Democratic Party. By using event study methodology on sample 177 listed firms, the results documented that in the nine days after the regime falling the value of firms connected with the National Democratic Party reduced by $13 \%$ more than other non-connected firms. The value of firms connected with the military increased and this given rise to increasing the board members who had a military title.

The study of Dang et al. (2018) revealed that connections to Mubarak contributed significantly, about $22.4 \%$, to firm value by offering benefits to Egyptian firms. But, when Mubarak lost power, the firms connected to his regime suffered a much heavier market-adjusted loss in stock price than the unconnected firms or firms with state-ownership only.

To date, the monarchy Arab countries received little attention. An exception to this Nasser (2019) who empirically investigated the impact of royal family members on firm performance of publicly listed companies in Saudi Arabia. Using 491 observations of publicly listed firms in Saudi Arabia's stock market between 2009 and 2013, the study found that firms with a high number of royal family members on the board had high Tobin's Q.

The third reason for contradicting results could be the type of the conducted study. Event studies and regression studies have been frequently used in empirical researches about the impact of political connections on firm value or performance (Liu et al., 2018). Event studies investigated market responses to political events that could affect firms' value in the short run. This approach has been widely used in the literature as it allows researchers to conduct their research in a relatively clear environment (Fisman, 2001; Berkman and Galpoththage, 2016; Wang, 2016; Liu et al., 2018; Green and Homroy, 2018; Wang et al., 2018; Dang et al., 2018). All of these studies used Cumulative Abnormal Return (CAR) to measure the firm value. While, regression studies aimed to examine the relationship between political connections and firm financial performance or value by considering other explanatory factors (Wang, 2015; Do et al.,2015; Chen et al., 2017; Shin et al., 2018; Lehrer, 2018).

Overall, it is obvious that there is a huge debate about the relationship between political connections and firm value. This leads to the first research hypothesis development:

$\mathbf{H}_{1}$ : There is a significant relationship between political connections and firm value.

This main hypothesis will be tested through the following sub-hypotheses:

$\mathbf{H}_{1 \mathrm{a}}$ : There is a significant relationship between political connectivity and Tobin's $\mathrm{Q}$.

$\mathbf{H}_{1 \mathrm{~b}}$ : There is a significant relationship between the strength of political connections and Tobin's $\mathrm{Q}$. 
INTERNATIONAL JOURNAL OF ACADEMIC RESEARCH IN BUSINESS AND SOCIAL SCIENCES Vol. 10, No. 9, 2020, E-ISSN: 2222-6990 @ 2020 HRMARS

\section{Related Party Transactions and Firm Value}

The agency problem usually refers to a conflict of interest between a company's management (agent) and its stockholders (principals). The agency problem arises when the principal delegates a decision making authority as an agent. The agent can make profits at the expense of the principals and stakeholders as suggested by information asymmetry theory (Elkelish, 2017; Pratama, 2018). The agency conflict can be expanded into a conflict between majority and minority stockholders. Majority stakeholders will try to absorb all the company profit and financial resources for themselves, an activity known as 'tunneling'. Tunneling activities are organized mainly through RPTs (Tambunan et al., 2017).

Generally, previous studies revealed no conclusive results concerning the impact of RPTs on the firm value. Some studies found that there was a positive relationship between them (Utama and Utama, 2014; Tsai et al., 2015; Downs et al., 2016; Nor and Ismail, 2017; Pratama, 2018), while others suggested that RPTs had a negative impact on the firm value (Bona-Sánchez et al., 2017; Elkelis, 2017).

Some studies revealed that RPTs could be either beneficial or harmful to shareholders depending on the types of transactions involved. The study of Huang and Liu (2010) conducted on high technology firms in China and Taiwan revealed that the accounts receivable and accounts payable from related parties had a positive impact on firm performance. The sales and purchases with related parties had a negative impact on firm performance.

Utama and Utama (2014) investigated the relationship between RPTs size and firm value in Indonesia. The results showed that the RPTs that involved loans and borrowings had positive effects on firm value but the RPTs that involved assets replacement had no effects on firm value. Tsai et al. (2015) examined the relationship between RPTs and corporate value in Taiwan. The results showed that the related party sales and purchases improved the affiliated firm value. Furthermore, the study of Tambunan et al. (2017) concluded that the RPTs of sales and income in addition to purchases and expenses had a positive relationship with firm value. On the other hand, RPTs of loans and assets tunneling had a negative impact on firm value in Indonesia.

Other studies revealed that RPTs could destroy or improve the value of shareholders depending on the type of parties involved in transactions such as the study of Nor and Ismail (2017). This study examined the impact of RPTs on firm value and whether this impact was moderated by characteristics of independent directors in Malaysia. The results revealed that there was a positive relationship between RPTs and firm performance and this relationship varied according to the parties involved in the transactions. Specifically, the firm performance was higher for RPTs with entities (such as subsidiaries, associates, and joint ventures).

Therefore, there is a continuing debate on the relationship between RPTs and firm value due to using different theories to investigate the relation, conducting the research in different environments and different regulatory settings and using different proxies for firm value. Based on this inconsistency the second research hypothesis is formulated as follows:

$\mathbf{H}_{2}$ : There is a significant relationship between related party transactions and firm value.

This main hypothesis will be tested through the following sub-hypotheses:

$\mathbf{H}_{\mathbf{2}}$ : There is a significant relationship between related party transactions related to assets and Tobin's Q.

$\mathbf{H}_{\mathbf{2 b}}$ : There is a significant relationship between related party transactions related to liabilities and Tobin's Q. 
INTERNATIONAL JOURNAL OF ACADEMIC RESEARCH IN BUSINESS AND SOCIAL SCIENCES Vol. 10, No. 9, 2020, E-ISSN: 2222-6990 @ 2020 HRMARS

\section{Political Connections, Related Party Transactions, and Firm Value}

Connections between firms and politicians are motivated by many benefits to both parties. Such as, firms relay on politicians to support them in fluctuating markets in terms of the tax burden and excessive regulations, and firms need to build political connections because the government has the power to allocate resources as suggested by resource dependence theory (Wu and Rui, 2012). From the politicians' side, firms help government officials to achieve their political goals, and government officials need resources to fund-raising their campaign during elections to remain in authority (Miettinen and Poutvaara, 2014).

There are many studies on the political connections and their advantages and disadvantage but there are limited researches on the mechanisms used by connected firms to expropriate minority resources. One of the proposed mechanisms is RPTs. RPTs allow firms with political connections to structure transactions among their affiliates (Cheung et al., 2009; Habib et al., 2017).

The study of Wang (2015) showed that a large number of politically connected firms, through independent directors, help to increase corporate value in private Chinese firms however were detrimental to corporate valuation in SOEs. Furthermore, having more directors with political ties enlarged RPTs in privately listed firms.

Habib et al. (2017) investigated whether politically connected firms utilize RPTs as a tunneling channel in Indonesia. The results of Habib's study showed that politically connected firms used related party loans to tunnel resources and that this impact was more pronounced for firms with government connections.

Sutrisno et al. (2019) examined the impact of political connections, RPTs, and the interaction between both on market performance. The results revealed that politically connected banks had higher ROE and Tobin's $Q$ than non-connected. These findings supported the argument of politically connected firms engaged in more RPTs. The results proved that the impacts of RPTs on market value were moderated by the index of the political connections. It was suggested that investors' perception of the existence of personal connected politics in the company into consideration of investors in seeing the effect of RPTs on bank performance.

Due to the limited literature regarding the relationship between political connections, RPTs, and firm value. The present research is attempted to contribute to the literature by providing empirical evidence regarding the effect of RPTs to tunnel resources and thereby reduce firm value in Egypt as one of the developing countries. Accordingly, the third research hypothesis is formulated as follows: $\mathbf{H}_{3}$ : Related party transactions moderate the relationship between political connections and firm value.

This main hypothesis will be tested through the following sub-hypotheses as political connections will be tested through connectivity and strength, further related party transactions related to assets and liabilities are considered:

$\mathbf{H}_{3 \mathbf{a}}$ : Related party transactions related to assets moderate the relationship between political connectivity and Tobin's Q.

$\mathbf{H}_{\mathbf{3}}$ : Related party transactions related to liabilities moderate the relationship between political connectivity and Tobin's Q.

$\mathbf{H}_{3 \mathbf{c}}$ : Related party transactions related to assets moderate the relationship between the strength of political connections and Tobin's Q.

$\mathbf{H}_{3 \mathrm{~d}}$ : Related party transactions related to liabilities moderate the relationship between the strength of political connections and Tobin's Q. 
INTERNATIONAL JOURNAL OF ACADEMIC RESEARCH IN BUSINESS AND SOCIAL SCIENCES Vol. 10, No. 9, 2020, E-ISSN: 2222-6990 @ 2020 HRMARS

\section{Research Design}

\section{Sample Selection}

The sampling method used in this research is purposive or judgemental sampling technique by using specific criteria. The initial sample includes Egyptian firms listed in the EGX 100 index as in August 2018. EGX 100 index has been employed as it includes the most 100 active firms in the market. Banks and financial service firms are excluded due to their unique nature of activities and they are subjected to different rules and regulations. To be included in the final sample, firms must meet the following criteria; First, firms provide the financial statements on the 31st of December as the financial statements of these firms are not homogeneous with the financial statements provided on the 30th of June. Second, firms publish consolidated financial statements because; the present research has privileged the consolidated accounts only. Third, firms disclose the size of RPTs at least in assets and liabilities.

The research sample covers a period of 5 years from 2014 to 2018 as 2014 can be considered as the beginning of the political stability in Egypt. The final sample ends up with 165 firm year observations, as shown in table (1).

Table (1): The Sample Selection

\begin{tabular}{|l|c|c|}
\hline Description & $\begin{array}{l}\text { Number of } \\
\text { firms }\end{array}$ & $\begin{array}{l}\text { Number of } \\
\text { observations }\end{array}$ \\
\hline Initial sample & $\mathbf{1 0 0}$ & $\mathbf{5 0 0}$ \\
\hline Less: Banks & 10 & 50 \\
\hline Financial services firms except banks & 15 & 75 \\
\hline $\begin{array}{l}\text { Firms provided financial statements on the } \\
\text { 30th of June }\end{array}$ & 18 & 90 \\
\hline $\begin{array}{l}\text { Firms publish standalone financial } \\
\text { statements }\end{array}$ & 18 & 90 \\
\hline Firms do not disclose the size of RPTs & 6 & 30 \\
\hline Final Sample & $\mathbf{3 3}$ & $\mathbf{1 6 5}$ \\
\hline
\end{tabular}

\section{The Variables Measurements}

The Dependent Variable

The dependent variable in this research is firm value. There are different measures of firm value. In the present research, the firm value is measured by Tobin's $Q$ because it is widely used in the literature as an indicator of the effectiveness of the company to generate future profits (Lei and Song, 2011; Chen et al., 2013; Liew et al., 2015; Tambunan et al., 2017; Chung et al., 2019). Tobin's Q is a good indicator of the firm's competitive advantages. Tobin's $Q$ is measured by using the following ratio; (total market value of equity + total of long term debts ) / (total of assets). The market value of equity equals the number of equity shares $x$ the closing price of the stock on the last day of the financial year. A result greater than 1 indicates investors have a positive outlook for the firm's growth opportunities

The Independent Variables

The first main independent variable is political connections. In the present research, political connections will be measured by using two proxies. The first proxy is Pc-connectivity to indicate whether the firm is politically connected or not. In line with Boubakri et al. (2008), the firm takes 1 if 
it has one or more of the firm's large shareholders or top administrators is an institution under governmental control, a member of the parliament, a minister, or is "closely-related" to top politicians. The second proxy for political connections is Pc-strength. It is used to indicate the connection strength by identifying the number of political connections in the firm. For example, a firm has four directors that are politically active now or in the past, the Pc-strength takes four (Egghe, 2019).

The second main independent variable is RPTs. Firms are obligated to disclose each item of assets and liabilities in the balance sheet as well as in the notes to financial statements, including the items arising from RPTs. Thus, the researcher uses two measures from the balance sheet and disclosure notes to measure the size of RPTs: assets and liabilities related to RPTs, with each expressed as a percentage of its total. RPTs related to assets (RPTA) consist of investments in associates and due from related parties. RPTs related to liabilities (RPTL) consist of loans/borrowings from related parties and due to related parties (Utama and Utama, 2014).

\section{The Control Variables}

Prior studies include many control variables that can affect the firm value, political connections and the size of RPTs. The most common variables are firm size, leverage, and audit firm size (Wang, 2015; Chen et al., 2017; Liu et al., 2016; Habib et al., 2017; Bona-Sánchez et al.,2017; Wang et al., 2018). Firm size (SIZE) measured by taking the natural logarithm of the total assets to normalize extreme values (Aggarwal and Padhan, 2017; Egghe, 2019). Leverage (LEV) is the ratio of debt to equity (Golubkov, 2016). Audit firm size (Audit) is measured by developing a dummy variable that is equal to one if the audit firm is a big 4 member and zero otherwise (Habib et al., 2017; Sutrisno, 2019).

\section{Research Models}

Political connections and firm value

To test $\mathrm{H}_{1}$, the following regression model is developed:

Tobin's $Q_{i t}=\alpha+\beta_{1}$ Pc-connect it $+\beta_{2}$ Pc-strength it $+\beta_{3}$ SIZE $_{i t}+\beta_{4}$ LEV $_{\text {it }}+\beta_{5}$ Audit it $+\varepsilon$ it (1)

Where,

Tobin's $Q_{i t}$ : Tobin's $Q$ for firm i at the end of year $t$.

Pc-connect it: Political connections connectivity for firm $i$ at the end of year $t$.

Pc-strength it: Political connections strength for firm $i$ at the end of year $t$

SIZE it $\quad$ : Firm size for firm $i$ at the end of year $t$.

LEV it : Financial Leverage for form $i$ at the end of year $t$.

Audit it : Audit firm size for firm $i$ at the end of year $t$.

$\varepsilon_{\text {it }} \quad:$ Residual error for firm $i$ at the end of year $t$.

Related Party Transactions and firm value

To test $\mathrm{H}_{2}$, the following regression model is developed:

Tobin's $Q_{\text {it }}=\alpha+\beta_{1}$ RPTA $_{\text {it }}+\beta_{2}$ RPTL $_{\text {it }}+\beta_{3}$ LEV $_{\text {it }}+\beta_{4}$ SIZE $_{i t}+\beta_{5}$ Auditit $_{\text {it }}+\varepsilon_{\text {it }}$

Where,

RPTA $A_{i t}$ : Related party transactions related to assets for firm $i$ at the end of year $t$.

RPTLit: Related party transactions related to liabilities for firm $i$ at the end of year $t$.

3.3.3 Poitical Connections, Related Party Transactions, and firm value

To test $\mathrm{H} 3$, the following regression model is developed 
INTERNATIONAL JOURNAL OF ACADEMIC RESEARCH IN BUSINESS AND SOCIAL SCIENCES Vol. 10, No. 9, 2020, E-ISSN: 2222-6990 @ 2020 HRMARS

Tobin's $Q_{i t}=\alpha+\beta_{1}$ PC-connect it $+\beta_{2}$ PC-strength ${ }_{i t}+\beta_{3}$ RPTA $_{i t}+\beta_{4}$ RPTL $_{i t}+\beta_{5}$ PC-connect $*$ RPTA $A_{i t}+\beta_{6}$ PC-connect * RPTL it $+\beta 7$ PC-strength * RPTA $A_{i t}+\beta_{8}$ PC-strength * RPTL $L_{i t}+\beta_{9}$ LEV $_{i t}+\beta_{10}$ $\mathrm{SIZE}_{i \mathrm{t}}+\beta_{11}$ Audit $_{i \mathrm{t}}+\varepsilon$ it

\section{Empirical Study}

Descriptive Statistics

This section presents a descriptive analysis of all variables used in this study. Table (2) presents the descriptive statistics of the continuous variables that involve the mean, the median, the maximum value, the minimum value, the standard deviation, the skewness, the kurtosis, and the Jarque-Bera test of each variable. Table (3) presents the descriptive statistics of dummy variables that include the frequency, the percent and the cumulative percent of dummy variables.

Table (2): Descriptive Statistics

\begin{tabular}{|l|l|l|l|l|l|l|}
\hline & Tobin's Q & RPTA & RPTL & Pc-strength & SIZE & LEV \\
\hline Mean & 0.878805 & 0.673889 & 0.040076 & 2.630303 & 21.92765 & 0.371576 \\
Median & 0.854373 & 0.559866 & 0.040076 & 2.000000 & 21.93006 & 0.300000 \\
Maximum & 1.765716 & 2.308797 & 0.109264 & 8.000000 & 25.29046 & 1.350000 \\
Minimum & 0.186721 & 0.000000 & 0.000000 & 0.000000 & 17.97022 & 0.000000 \\
Std. Dev. & 0.341242 & 0.576921 & 0.029787 & 2.045889 & 1.783050 & 0.328516 \\
Skewness & 0.382265 & 0.763635 & 0.676081 & 0.745586 & -0.103915 & 0.815658 \\
Kurtosis & 2.551658 & 2.647016 & 2.638151 & 3.234432 & 2.082031 & 2.847931 \\
Jarque-Bera & 5.400431 & 16.89291 & 13.47003 & 15.66504 & 6.053385 & 18.45467 \\
Probability & 0.067191 & 0.000215 & 0.001189 & 0.000397 & 0.048476 & 0.000098 \\
Observations & 165 & 165 & 165 & 165 & 165 & 165 \\
\hline
\end{tabular}

Table (2) presents descriptive statistics for the sample. The Tobin's $Q$ of the sample firms ranges from (0.187) to (1.766) with a mean and median value of (0.879) and (0.854), respectively over the entire sample period. These values indicate that the majority of the firms in the sample are undervalued as, Tobin's $Q$ less than 1 which means the book value of the firm is more than the market value of the firm.

The mean (median) values of the RPTA and RPTL are $0.674(0.560)$ and 0.040 (0.040). The minimum value of both is 0 this means that conducting transactions with a related party is optional for firms according to their needs. Additionally, the mean value of Pc-strength is (2.630) and the median is (2). The range of Pc-strength in the sample is from (0) to (8) which means the maximum number of politically connected people in one firm is 8 .

The normality of the variables examined using kurtosis and skewness. The variables can be assumed if the skewness statistic is within the interval $(-1,+1)$. Skewness is an indicator used in distribution analysis as a sign of asymmetry and deviation from the normal distribution. The variables can be assumed normally distributed if the kurtosis statistic is lying in the interval $(-3,+3)$. The skewness and (Kurtosis) values of Tobin's Q, RPTA, RPTL, Pc-strength, SIZE, and LEV are indicating that the values of variables are normally distributed, as its skewness values are between -1 and +1 and Kurtosis values of all variables approximately near to 3.

Additionally, the "jarque-bera test" is used to measure the normality distribution of all variables in this research with a significance value greater than 0.05 . Therefore; Tobin's $Q$ is normally distributed at $(5.40, p$-value $=0.067)$. On the other hand, the research variables in terms of RPTA, RPTL, PC- 
INTERNATIONAL JOURNAL OF ACADEMIC RESEARCH IN BUSINESS AND SOCIAL SCIENCES Vol. 10, No. 9, 2020, E-ISSN: 2222-6990 @ 2020 HRMARS

strength, SIZE, and LEV are not normally distributed since the significance of Jarque-Bera statistic is less than (0.05).

Table (3): Descriptive Statistics of Dummy Variables.

\begin{tabular}{|l|l|l|l|l|}
\hline \multicolumn{2}{|l|}{ Research dummy variables } & Frequency & Percentage & $\begin{array}{l}\text { Cumulative } \\
\text { percentage }\end{array}$ \\
\hline Pc-connect & Not connected & 31 & $18.8 \%$ & $18.8 \%$ \\
& connected & 134 & $81.2 \%$ & $100 \%$ \\
\hline Audit & Non big 4 & 49 & $29.7 \%$ & $29.7 \%$ \\
& Big 4 & 116 & $70.3 \%$ & $100 \%$ \\
\hline
\end{tabular}

As can be seen from the table (3), the frequency of not politically connected observations is 31 (18.8\%) and the frequency of politically connected observations 134 (81.2\%). It can be revealed that most firms in the sample are politically connected. Additionally, the frequency of firms that audited by non-big 4 firms is 49 (29.7\%) and the frequency of firms that audited by big 4 firms is 116 (70.3\%) which means that the most firms in the sample with high audit quality as they audited by big 4 audit firms.

\section{Diagnostic Statistics}

The diagnostic tests are carried out on all data before running the regression analysis to verify the validity of all variables and the research models. Additionally, they are used to assure that the results will not be biased. These tests include a group unit root test, a multicollinearity test, a co-integration test, a heteroskedasticity test, a serial correlation test, a model specification test, and a heterogeneity test.

\section{Group Unit Root Test}

"Group unit root test" is used to test for stationary in a time series that enable the researcher to generalize the results to future periods. A stationary time series means that the variables means and variances are constant over time. Table (4) presents the group unit root test for Tobin's Q, RPTA, RPTL, PC-strength, SIZE, and LEV.

Table (4): Group Unit Root Test.

\begin{tabular}{|lll|}
\hline Method & Statistic & Prob. \\
\hline Null: Unit root (assumes common unit root process) & & \\
\hline Levin, Lin \& Chu t & -2.55119 & 0.0054 \\
\hline Null: Unit root (assumes individual unit root process) & & \\
\hline Im, Pesaran and Shin W-stat & -7.34562 & 0.0000 \\
\hline ADF - Fisher Chi-square & 89.5495 & 0.0000 \\
\hline PP - Fisher Chi-square & 129.524 & 0.0000 \\
\hline
\end{tabular}

Table (4) shows that the P-values of LLC, IPSW, ADF, and PP tests are less than (0.05). This means that Tobin's Q, RPTA, RPTL, PC-strength, SIZE, and LEV in the current research have a stationary time series. Thus, the present research results can be generalized to future periods.

Multicollinearity Test

Pearson's correlation measures the strength and direction of the linear relationship between every two variables. Besides, this test detects the multicollinearity problem. 
INTERNATIONAL JOURNAL OF ACADEMIC RESEARCH IN BUSINESS AND SOCIAL SCIENCES

Vol. 10, No. 9, 2020, E-ISSN: 2222-6990 @ 2020 HRMARS

Table (5): Pearson's Correlation Matrix

\begin{tabular}{|c|c|c|c|c|c|c|c|c|}
\hline & Tobin's Q & Pc-connect & $\begin{array}{l}\text { Pc- } \\
\text { strength }\end{array}$ & RPTA & RPTL & LEV & SIZE & Audit \\
\hline & (1) & (2) & (3) & (4) & (5) & (6) & (7) & (8) \\
\hline (1) & 1.00000 & & & & & & & \\
\hline (2) & $\begin{array}{l}0.253857 \\
0.0010 * * *\end{array}$ & $\begin{array}{l}1.00000 \\
----\end{array}$ & & & & & & \\
\hline (3) & $\begin{array}{l}0.291469 \\
0.0001 * * *\end{array}$ & $\begin{array}{l}0.586027 \\
0.0000 * * *\end{array}$ & $\begin{array}{l}1.00000 \\
----\end{array}$ & & & & & \\
\hline (4) & $\begin{array}{l}0.163275 \\
0.0361^{* *}\end{array}$ & $\begin{array}{l}0.029040 \\
0.7112\end{array}$ & $\begin{array}{l}-0.140298 \\
0.0723^{*}\end{array}$ & 1.00000 & & & & \\
\hline (5) & $\begin{array}{l}-0.193453 \\
0.0128 * *\end{array}$ & $\begin{array}{l}-0.181714 \\
0.0195^{* *}\end{array}$ & $\begin{array}{l}-0.165080 \\
0.0341^{* *}\end{array}$ & $\begin{array}{l}-0.041746 \\
0.5945\end{array}$ & $\begin{array}{l}1.00000 \\
----\end{array}$ & & & \\
\hline (6) & $\begin{array}{l}0.131422 \\
0.0924^{*}\end{array}$ & $\begin{array}{l}0.173567 \\
0.0258 * *\end{array}$ & $\begin{array}{l}0.182590 \\
0.0189 * *\end{array}$ & $\begin{array}{l}-0.014066 \\
0.8577\end{array}$ & $\begin{array}{l}-0.157697 \\
0.0431^{* *}\end{array}$ & 1.00000 & & \\
\hline (7) & $\begin{array}{l}0.111716 \\
0.1531\end{array}$ & $\begin{array}{l}0.352157 \\
0.0000^{* * *}\end{array}$ & $\begin{array}{l}0.435180 \\
0.0000 * * *\end{array}$ & $\begin{array}{l}-0.032688 \\
0.6768\end{array}$ & $\begin{array}{l}-0.502650 \\
0.0000^{*} * *\end{array}$ & $\begin{array}{l}0.305009 \\
0.0001^{* * *}\end{array}$ & 1.00000 & \\
\hline (8) & $\begin{array}{l}0.202325 \\
0.0092 * * *\end{array}$ & $\begin{array}{l}0.366525 \\
0.0000 * * *\end{array}$ & $\begin{array}{l}0.503230 \\
0.0000 * * *\end{array}$ & $\begin{array}{l}-0.040778 \\
0.6030\end{array}$ & $\begin{array}{l}-0.303774 \\
0.0001 * * *\end{array}$ & $\begin{array}{l}0.227082 \\
0.0034 * * *\end{array}$ & $\begin{array}{l}0.341072 \\
0.0000 * * *\end{array}$ & $\begin{array}{l}1.00000 \\
-----\end{array}$ \\
\hline
\end{tabular}

$*, * *, * * *$ Significant at the 10,5 , and 1 percent levels, respectively

From table (5), there are significant positive correlations between the independent variables (Pcconnect, Pc-strength, RPTA, LEV, and Audit) and the dependent variable which is Tobin's Q. Furthermore, there is a significant negative correlation between RPTL and Tobin's Q as ( $r=-0.193453$ ) and (P-value < 0.05). However, the results show that there is an insignificant correlation between firm size and Tobin's Q. Additionally, the highest correlation exists between Pc-connect and Pcstrength $(r=0.586)$. Therefore, there are no multicollinearity problems because there is no correlation higher than (0.8) between variables.

Other diagnostics tests

Before running the regression model the following diagnostic tests are conducted on the data of the empirical models. 
INTERNATIONAL JOURNAL OF ACADEMIC RESEARCH IN BUSINESS AND SOCIAL SCIENCES Vol. 10, No. 9, 2020, E-ISSN: 2222-6990 @ 2020 HRMARS

Table (6): Other diagnostics tests

\begin{tabular}{|c|c|c|c|c|c|}
\hline \multicolumn{2}{|c|}{ Test } & Model (1) & Model (2) & Model (3) & Result \\
\hline \multirow{2}{*}{$\begin{array}{l}\text { Kao Cointegration } \\
\text { Test }\end{array}$} & t-statistic & -2.896878 & -3.726030 & -4.205958 & \multirow[b]{2}{*}{$\begin{array}{l}\text { There are long- } \\
\text { term equilibrium } \\
\text { relationships } \\
\text { among the } \\
\text { variables of the } \\
\text { panel data model }\end{array}$} \\
\hline & Probabiliy & 0.0019 & 0.0001 & 0.0000 & \\
\hline \multirow{4}{*}{$\begin{array}{l}\text { Heteroskedasticity } \\
\text { Test }\end{array}$} & F-statistic & 1.043601 & 1.161825 & 3.487657 & \multirow{4}{*}{$\begin{array}{c}\text { There is } \\
\text { homoscedasticity } \\
\text { (error terms have } \\
\text { constant variance) } \\
\text { in the models }\end{array}$} \\
\hline & Prob. F & 0.3993 & 0.2827 & 0.0636 & \\
\hline & Obs*Rsquared & 6.289923 & 1.167831 & 3.456114 & \\
\hline & Prob.ChiSquare & 0.3915 & 0.2798 & 0.0630 & \\
\hline \multirow{4}{*}{$\begin{array}{l}\text { Serial Correlation } \\
\text { Test }\end{array}$} & F-statistic & 1.252623 & 1.885908 & 2.066665 & \multirow{4}{*}{$\begin{array}{l}\text { There is no serial } \\
\text { correlation in the } \\
\text { empirical models }\end{array}$} \\
\hline & Prob. F & 0.2886 & 0.1552 & 0.1302 & \\
\hline & Obs*Rsquared & 2.608550 & 3.896019 & 4.426641 & \\
\hline & Prob.ChiSquare & 0.2714 & 0.1426 & 0.1093 & \\
\hline \multirow{3}{*}{$\begin{array}{l}\text { Ramsey's } \\
\text { Regression } \\
\text { Specification Error } \\
\text { Test }\end{array}$} & $\begin{array}{l}\text { Value } \\
\text { df } \\
\text { Probability }\end{array}$ & $\begin{array}{c}0.927434 \\
156 \\
0.3551 \\
\end{array}$ & $\begin{array}{c}0.825479 \\
156 \\
0.4104 \\
\end{array}$ & $\begin{array}{c}0.110492 \\
150 \\
0.9122 \\
\end{array}$ & \multirow{3}{*}{$\begin{array}{c}\text { The functional } \\
\text { form is correct and } \\
\text { no omitted } \\
\text { variables in the } \\
\text { models }\end{array}$} \\
\hline & $\begin{array}{l}\text { Value } \\
\text { df } \\
\text { Probability }\end{array}$ & $\begin{array}{c}0.860133 \\
(1,156) \\
0.3551\end{array}$ & $\begin{array}{c}0.681416 \\
(1,156) \\
0.4104\end{array}$ & $\begin{array}{c}0.012208 \\
(1,150) \\
0.9122\end{array}$ & \\
\hline & $\begin{array}{l}\text { Value } \\
\text { df } \\
\text { Probability }\end{array}$ & $\begin{array}{c}0.901759 \\
1 \\
0.3423\end{array}$ & $\begin{array}{c}0.714800 \\
1 \\
0.3979\end{array}$ & $\begin{array}{c}0.013347 \\
1 \\
0.9080\end{array}$ & \\
\hline \multirow[t]{3}{*}{ Hausman Test } & Chi-Sq. Statistic & 91.967408 & 13.667369 & 87.699261 & \multirow{3}{*}{$\begin{array}{c}\text { The suitable panel } \\
\text { model is Fixed } \\
\text { Effect Model (FEM) } \\
\text { not Random Effect } \\
\text { Model (REM) }\end{array}$} \\
\hline & Chi-Sq. d.f. & 5 & 5 & 11 & \\
\hline & Prob. & 0.0000 & 0.0179 & 0.0000 & \\
\hline
\end{tabular}

After conducting the diagnostic tests, it can be revealed that the empirical models in the current research are free from heteroskedasticity, autocorrelation, and multicollinearity, and model misspecified problems. Furthermore, FEM is a suitable model to test the research hypotheses based on the Hausman test. 
INTERNATIONAL JOURNAL OF ACADEMIC RESEARCH IN BUSINESS AND SOCIAL SCIENCES Vol. 10, No. 9, 2020, E-ISSN: 2222-6990 @ 2020 HRMARS

\section{Empirical Results}

Table (6): Total Panel Estimation FEM to Determine the Effect of Independent Variables on Tobin's Q

\begin{tabular}{|c|c|c|c|}
\hline Variable & Model (1) & Model (2) & Model (3) \\
\hline Pc-connect & $\begin{array}{l}0.396792 \\
0.0332 * *\end{array}$ & - & $\begin{array}{c}0.447435 \\
0.0914 *\end{array}$ \\
\hline Pc-strength & $\begin{array}{c}0.070098 \\
0.0715^{*}\end{array}$ & - & $\begin{array}{l}0.074501 \\
0.0104 * *\end{array}$ \\
\hline RPTA & - & $\begin{array}{c}0.109214 \\
0.0000 * * *\end{array}$ & $\begin{array}{c}0.284738 \\
0.1478\end{array}$ \\
\hline RPTL & - & $\begin{array}{c}-0.232263 \\
0.6730\end{array}$ & $\begin{array}{l}-2.623706 \\
0.0003 * * *\end{array}$ \\
\hline Pc- connect $*$ RPTA & - & - & $\begin{array}{c}-0.190591 \\
0.3941\end{array}$ \\
\hline Pc- connect * RPTL & - & - & $\begin{array}{c}2.255281 \\
0.3811\end{array}$ \\
\hline Pc- strength * RPTA & - & - & $\begin{array}{c}-0.008430 \\
0.7171\end{array}$ \\
\hline Pc- strength * RPTL & - & - & $\begin{array}{c}0.031914 \\
0.9522\end{array}$ \\
\hline SIZE & $\begin{array}{c}0.092481 \\
0.2179 \\
\end{array}$ & $\begin{array}{c}0.071892 \\
0.2406 \\
\end{array}$ & $\begin{array}{c}0.089629 \\
0.1087 \\
\end{array}$ \\
\hline LEV & $\begin{array}{c}0.120766 \\
0.2242 \\
\end{array}$ & $\begin{array}{c}0.109107 \\
0.3843\end{array}$ & $\begin{array}{c}0.072097 \\
0.4693\end{array}$ \\
\hline Audit & $\begin{array}{c}0.072399 \\
0.1574\end{array}$ & $\begin{array}{l}0.176839 \\
0.176839\end{array}$ & $\begin{array}{c}0.069291 \\
0.3304\end{array}$ \\
\hline C & $\begin{array}{c}-1.752464 \\
0.3371\end{array}$ & $\begin{array}{c}-0.927526 \\
0.4947\end{array}$ & $\begin{array}{c}-1.761660 \\
0.2113\end{array}$ \\
\hline R-squared & 0.746444 & 0.745709 & 0.759042 \\
\hline Adjusted R-squared & 0.661925 & 0.660945 & 0.662248 \\
\hline F-statistic & 8.831711 & 8.797507 & 7.841761 \\
\hline Prob(F-statistic) & 0.00000 & 0.000000 & 0.000000 \\
\hline Durbin-Watson stat & 1.813862 & 1.821217 & 1.957770 \\
\hline
\end{tabular}


INTERNATIONAL JOURNAL OF ACADEMIC RESEARCH IN BUSINESS AND SOCIAL SCIENCES

Vol. 10, No. 9, 2020, E-ISSN: 2222-6990 @ 2020 HRMARS

$*, * *, * * *$ Significant at the 10,5 , and 1 percent levels, respectively.

Results Regarding the Relationship between Political Connections and Firm value

As shown in the table (6), there is a significant positive effect for Pc-connect and Pc-strength on Tobin's $Q$. This means that the firms with political connections have a higher value than firms without political connections and firms with a high number of politically connected members have a higher Tobin's than firms with a low number of politically connected members. Thus, $\mathrm{H}_{1 \mathrm{a}}$ and $\mathrm{H}_{1 b}$ are accepted. Furthermore, firm size, leverage, and audit quality have insignificant effects on Tobin's $Q$.

The Independent Variables were accepted in the model (Pc-connect, Pc-strength, SIZE, LEV, Audit) can explain (74.64\%) from the total variation of the dependent variable (Tobin's Q), and the rest percent $(25.36 \%)$ is explained due to either the random error in the regression model or other independent variables excluded from the regression model.

The value of the F-test is (8.832) which show the overall significance of the model. The model is significant because of the significant value $(p=0.000)$ is less than $(0.05)$. It can be concluded that the independent variables that were accepted in the model have effects on Tobin's $Q$.

The Durbin-Watson test statistic tests the null hypothesis that the residuals from the regression are not autocorrelated. The Durbin-Watson statistic ranges in value from 0 to 4 . A value near 2 indicates non-autocorrelation; a value toward 0 indicates positive autocorrelation; a value toward 4 indicates negative autocorrelation. Since the test statistic value (1.8) was near to 2, therefore the null hypothesis is accepted which means there is no autocorrelation.

Results Regarding the Relationship between Related Party Transactions and Firm value

As shown in the table (6), there is a significant positive effect for RPTA and Audit quality on Tobin's $Q$ thus, H2a can be accepted. While RPTL has an insignificant negative effect on Tobin's Q therefore, $\mathrm{H} 2 \mathrm{~b}$ is rejected. This means that the firm with RPTA has a higher Tobin's Q.

Furthermore, firm size and leverage have insignificant effects on Tobin's Q. The most significant independent variables that are accepted in the model are RPTA and Audit at a significant level of less than $1 \%$ and $5 \%$ respectively. The independent variables were accepted in the model (RPTA, RPTL, LEV, SIZE, Audit ) explain (74.6\%) from the total variation of the dependent variable (Tobin's Q), and the rest percent due to either the random error in the regression model or other independent variables excluded from the regression model.

"F test" is a test to determine if there is a linear relationship between the dependent variable and a subset of the independent variables. Since the value of the "F test" is (8.797507) with a P-value less than (.05), then the researcher concludes that the independent variables were accepted in the model have effects on the level of Tobin's Q. The Durbin-Watson test statistic is (1.8) thus; the null hypothesis can be accepted. It can be concluded that there is no autocorrelation.

Results about the Relationship between Political Connections, Related Party Transactions, and Firm value

As shown in the table (6), there is a significant positive effect for Pc-connect and Pc- strength on Tobin's Q while, RPTL has a negative significant effect on Tobin's $Q$. The rest of the independent variables have an insignificant effect on Tobin's $\mathrm{Q}$. Thus, H3 that states “ related party transactions moderate the relationship between political connections and firm value" can be rejected which means RPTs could not be used by politically connected firms to raise Tobin's Q. 
INTERNATIONAL JOURNAL OF ACADEMIC RESEARCH IN BUSINESS AND SOCIAL SCIENCES Vol. 10, No. 9, 2020, E-ISSN: 2222-6990 @ 2020 HRMARS

The independent variables were accepted in the model can explain (75.9\%) from the total variation of the dependent variable (Tobin's Q), and the rest percent $(24.1 \%)$ is explained due to either the random error in the regression model or other independent variables excluded from the regression model. The value of the F-test is (7.8) which shows the overall significance of the model. The model is significant because of the significant value $(p=0.000)$ is less than $(0.05)$.

The Durbin-Watson test value is (1.96) that is near to 2, therefore the null hypothesis is accepted which means there is no autocorrelation. The value of $U$ Theil's inequality is (0.09) indicating the goodness of fit of the panel model, at a percent of not less than (91\%).

\section{Discussion of the Findings}

This section discusses the main findings of the current research. The descriptive statistics indicate that most of the sample firms are politically connected and audited by big 4 audit firms. The average of the sample firms have Tobin's $Q$ values less than 1 that indicates the market values of the firms are less than their book values. Therefore, firms might be viewed as having a low competitive advantage and poor growth opportunities as Tobin's $Q$ evaluates not only the recorded assets but also the market outlook and the analysts' prediction for the future.

Propping and tunneling are the main behavior patterns of RPTs (Riyanto and Toolsema, 2008). Propping is the transfer of resources to avoid bankruptcy or maintain the listing position. Conversely, tunneling is the transfer of the company funds through loan guarantees and intercompany loans, and paying too much executive compensation in order to expropriate the minority wealth (Downs et al., 2016).

The descriptive statistics indicate that the sample firms engaged more RPTA than RPTL. This finding suggests that most firms are involved in RPTs for propping up than for tunneling as RPTA include the investments with associates and the due from related parties and these accounts are less likely to be manipulated to expropriate minority wealth.

Regarding the analysis of the regression models, it is found that there is a significant positive impact of the connectivity of the firm with politicians and the number of political connections on firm value. The results show a significant positive relation between political connectivity and Tobin's $Q$. Furtheremore, they show a significant positive relationship between political connections strength and Tobin's $\mathrm{Q}$. Based on these findings, $\mathrm{H}_{1 \mathrm{a}}$ and $\mathrm{H}_{1 \mathrm{~b}}$ can be accepted. Taken together, the results do not find evidence that political connections can reduce the firm value. Therefore, $\mathrm{H}_{1}$ can be accepted. It is concluded that the results regarding the relationship between political connections and firm value are consistent with the results of prior studies that support the "helping hands view" or "value adding view" (Fisman, 2001; Wu et al., 2012; Do et al., 2015; Green and Homroy, 2018; Wang et al, 2018; Shin et al., 2018; Wu et al., 2018; Chung et al., 2019). They argued that the political connections enhance firm value by facilitating the acquisition of scarce resources, providing protection especially in weak institutional settings, reducing taxes, enhancing reputation and providing lighter regulatory control.

Concerning the impact of RPTs on Tobin's Q, RPTA have a significant positive effect on Tobin's Q while RPTL have an insignificant effect on Tobin's Q. This means that RPTA can improve the firm's competitive advantage and they increase the growth opportunities in the future as more RPTA imply more investments in associates. In other words, RPTA are used by firms to achieve propping up goals such as, such as meeting earnings targets and maintaining their listing status. Hence, $\mathrm{H}_{2 a}$ can be accepted while $\mathrm{H}_{2 b}$ can be rejected. 
INTERNATIONAL JOURNAL OF ACADEMIC RESEARCH IN BUSINESS AND SOCIAL SCIENCES Vol. 10, No. 9, 2020, E-ISSN: 2222-6990 @ 2020 HRMARS

Taken together, the results do not find evidence that RPTs are carried out mainly for abusive motives in the sample of Egyptian firms. The finding of the positive impact of RPTs on firm value are consistent with the prior studies that support the efficient transactions theory (Cheung et al,.2006; Chen et al.,2009; Kohlbeck and Mayhew, 2010; Huang and Liu, 2010; Utama and Utama, 2014; Wong et al.,2015; Tsai et al., 2015; Downs et al., 2016; Nor and Ismail, 2017; Pratama, 2018).

In terms of the moderating role of RPTs on the relationship between political connections and firm value, FEM regression results show RPTs fail to moderate the relationship between political connections and Tobin's $Q$. Since, all interaction variables have an insignificant effect on Tobin's $Q$. However, this result has not previously been described. The results are inconsistent with the limited studies in the moderating effect of RPTs on the relationship between political connections and firm value that suggest the RPTs used as an expropriating tool (Habib et al., 2017).

These different findings may be interpreted by using different proxies of firm value and conducting the research in a different environment that are different from Egypt such as, China (Wang et al., 2010) and Indonesia (Habib et al., 2017; Sutrison et al., 2019) that argue that there is a moderating role of RPTs on the relationship between political connections and firm value. Overall, the first and second main hypotheses of the present research can be accepted and the third main hypothesis can be rejected.

\section{Conclusion}

The main purpose of the current research is to examine the impact of political connectedness and related party transactions on firm value. Moreover, this research investigates the impact of related party transactions on the relationship between political connections and firm value. Egypt is particularly suitable for these investigations as both political connections and RPTS are invasive and, thus, are expected to affect the firm value significantly. This research covers a period from 2014 to 2018 and includes a final sample consisted of 33 firms ending up with $165 \mathrm{f}$ The results show a significant positive impact of political connectivity and political strength on firm value. These results are consistent with the results of prior studies that support the "helping hands view" (Fisman, 2001; Wu et al., 2012; Do et al., 2015; Green and Homroy, 2018; Wang et al, 2018; Shin et al., 2018; Wu et al., 2018; Chung et al., 2019).

Additionally, The results of the regression can suggest that RPTs in Egypt are carried out mainly for efficient motives. The finding of the positive impact of RPTs on firm value are consistent with the prior studies that support the efficient transactions theory (Cheung et al,.2006; Chen et al.,2009; Kohlbeck and Mayhew, 2010; Huang and Liu, 2010; Utama and Utama, 2014; Wong et al.,2015; Tsai et al., 2015; Downs et al., 2016; Nor and Ismail, 2017; Pratama, 2018).

Furthermore, the current research examines whether RPTs can moderate the relationship between political connections and form value. FEM regression results show RPTs fail to moderate the relationship between political connections and Tobin's $Q$.

The results are inconsistent with the limited studies in the moderating effect of RPTs on the relationship between political connections and firm value that suggest the RPTs used as an expropriating tool (Habib et al., 2017; Sutrison et al., 2019). These different findings may be interpreted by using different measures and conducting the research in a different environment. Overall, the first and second main hypotheses of the present research can be accepted and the third main hypothesis can be rejected. 
INTERNATIONAL JOURNAL OF ACADEMIC RESEARCH IN BUSINESS AND SOCIAL SCIENCES Vol. 10, No. 9, 2020, E-ISSN: 2222-6990 @ 2020 HRMARS

This research contributes to accounting and finance literature by examining empirically the impact of political connections and RPTs on firm value. The results conclude that political connections and related party transactions related to assets improve firm value.

The results of the present research are potentially useful to regulators, who will benefit from an understanding of how the presence of political connections on boards affects firm value. In particular, the results suggest that in countries where recent reforms aim to improve minority investor protection and market confidence, regulators should consider the composition of outside directors as well as explicit board independence.

The results may benefit the managers of firms to increase their investments and transactions with associates that can improve firm value. The results of the current research may also be useful to investors, financial analysts, and auditors, as they highlight the importance of considering specific features in evaluating firms.

Based on the research findings, there are some suggestions for future research:

1- Extending the empirical study to consider the effect of different types of political connections on firm value.

2- Employing other proxies for firm value.

3- Expanding the sample period to increase the sample size in future research irm-year observations.

4- Considering the corporate governance mechanisms.

5- Considering the corporate social responsibility activities.

\section{References}

Acemoglu, D., Hassan, T. A., and Tahoun, A. ( 2017). The Power of The Street: Evidence From Egypt's Arab Spring. The Review of Financial Studies, Vol.31 No.1, pp.1-42.

Aggarwal, D., and Padhan, P. C. (2017). Impact of capital structure on firm value: evidence from Indian Hospitality Industry. Theoretical Economics Letters, Vol.7 No.4, pp.982-1000.

Berkman, H., and Galpoththage, V. (2016). Political Connections and Firm Value: An Analysis of Listed Firms in Sri Lanka. Pacific Accounting Review, Vol.28 No.1, pp.92-106.

Bona-Sanchez, C., Fernández-Senra, C. L., and Perez-Aleman, J. (2017). Related-Party Transactions, Dominant Owners and Firm Value. BRQ Business Research Quarterly, Vol.20 No.1, pp.4-17.

Boubakri, N., Cosset, J. C., and Saffar, W. (2008). Political Connections of Newly Privatized Firms. Journal of Corporate Finance, Vol.14 No.5, pp.654-673.

Chaney, P. K., Faccio, M., and Parsley, D. (2011). The Quality of Accounting Information in Politically Connected Firms. Journal of Accounting and Economics, Vol.51 No,1-2, pp.58-76.

Chen, C. R., Li, Y., Luo, D., and Zhang, T. (2017). Helping Hands or Grabbing Hands? An Analysis of Political Connections and Firm Value. Journal of Banking \& Finance, Vol 80, pp.71-89.

Cheung, Y. L., Jing, L., Lu, T., Rau, P. R., and Stouraitis, A. (2009). Tunneling and Propping Up: An Analysis of Related Party Transactions by Chinese Listed Companies. Pacific-Basin Finance Journal, Vol. 17 No.3, pp.372-393.

Choi, M. (2014). The Value of Political Connections: Evidence From Korean Chaebols. Unpublished Doctoral dissertation. Queensland University of Technology.

Chung, C. Y., Byun, J. H., and Young, J. (2019). Corporate Political Ties and Firm Value: Comparative Analysis in the Korean Market. Sustainability, Vol.11 No.2, pp.327.

Dang, V. Q., So, E. P., and Yan, I. K. (2018). The Value of Political Connection: Evidence from The 2011 Egyptian Revolution. International Review of Economics \& Finance, Vol.56, pp.238-257. 
INTERNATIONAL JOURNAL OF ACADEMIC RESEARCH IN BUSINESS AND SOCIAL SCIENCES Vol. 10, No. 9, 2020, E-ISSN: 2222-6990 @ 2020 HRMARS

Diwan, I., Keefer, P., and Schiffbauer, M. (2015). Pyramid Capitalism:political Connections, Regulation, and Firm Productivity in Egypt Policy. Research Working Paper No. 7354. Available at: https://openknowledge.worldbank.org/handle/10986/22236..

Do, Q. A., Lee, Y. T., and Nguyen, B. D. (2015). Political connections and firm value: Evidence from the regression discontinuity design of close gubernatorial elections. LIEPP Working Paper.

Downs, D. H., Ooi, J. T., Wong, W. C., and Ong, S. E. (2016). Related Party Transactions and Firm Value: Evidence from Property Markets in Hong Kong, Malaysia and Singapore. The Journal of Real Estate Finance and Economics, vol.52 No.4, pp.408-427.

Du, F. (2011). Political Connections and Access to Bond Capital: Reputation or Collusion?. Unpublished Ph. D. Thesis. University of Southern California.

Egghe, L. (2019). Political connections and tax avoidance analysis in Belgium. Unpublished Master dissertation,Ghent University.

ElKelish, W. W. (2017). Related Party Transactions Disclosure in The Emerging Market of The United Arab Emirates. Accounting Research Journal, Vol. 30 No.4, pp.362-378.

Faccio, M., and Lang, L. H. (2002). The ultimate ownership of Western European corporations. Journal of Financial Economics, Vol.65 No.3, pp.365-395.

Faccio, M. (2006). Politically Connected Firms. American economic review, Vol.96 No.1, pp.369-386.

Fisman, R. (2001). Estimating The Value of Political Connections. American economic review . Vol.91 No.4, pp.1095-1102.

Golubkov, D. (2016). Corporate political connections in Russia and their implications for firm-level operational, financial, and investment activities. Unpublished Doctoral dissertation, ESSEC Business School (France).

Green, C. P., and Homroy, S. (2018). Corporate Boards and The Value of Political Connections. Availableat:

https://www.researchgate.net/profile/Swarnodeep_Homroy/publication/328748545_Bringi ng_Connections_Onboard_The_Value_of_Political_Influence/links/5be18943299bf1124fbe5 050/Bringing-Connections-Onboard-The-Value-of-Political-Influence.pdf

Gujarati, D. N. (2015). Econometrics by Examples. Second Edition. Macmillan Education Palgrave.

Habib, A., Muhammadi, A. H., and Jiang, H. (2017). Political Connections and Related Party Transactions: Evidence from Indonesia. The International Journal of Accounting, Vol.52 No.1, pp.45-63.

Huang, D. T., and Liu, Z. C. (2010). A Study of The Relationship between Related Party Transactions and Firm Value in High Technology Firms in Taiwan and China. African Journal of Business Management, Vol.4 No.9, pp.1924-1931.

International Accounting Standard Board (IASB). (2009) International Accounting Standards (IAS) No. 24: Disclosure of Related Party Transactions. London: IFRS Foundation.

Kohlbeck, M., and Mayhew, B. W. (2010). Valuation of Firms That Disclose Related Party Transactions. Journal of Accounting and Public Policy, Vol. 29 No.2, pp.115-137.

Lehrer, N. D. (2018). The Value of Political Connections in A Multiparty Parliamentary Democracy: Evidence from The 2015 Elections in Israel. European Journal of Political Economy, Vol.53, pp.13-58.

Lei, A. C., and Song, F. M. (2011). Connected Transactions and Firm Value: Evidence from ChinaAffiliated Companies. Pacific-Basin Finance Journal, Vol.19 No.5, pp.470-490. 
INTERNATIONAL JOURNAL OF ACADEMIC RESEARCH IN BUSINESS AND SOCIAL SCIENCES

Vol. 10, No. 9, 2020, E-ISSN: 2222-6990 @ 2020 HRMARS

Liu, F., Lin, H., and Wu, H. (2018). Political Connections and Firm Value in China: An Event Study. Journal of Business Ethics, Vol. 152 No. 2, pp.551-571.

Miettinen, T., and Poutvaara, P. (2014). A Market For Connections. European Journal of Political Economy, Vol. 33, pp.37-52.

Nasser, Z. A. (2019). The effect of royal family members on the board on firm performance in Saudi Arabia.Journal of Accounting in Emerging Economies. Available at: https://www.emerald.com/insight/content/doi/10.1108/JAEE-04-2017-0041/full/html

Nor, H. M., and Ismail, K. N. I. K. (2017). The Moderating Effects of Independent Directors' Human Capital on The Relationship between Related Party Transactions and Firm Performance: Evidence from Malaysia. Jurnal Pengurusan (UKM Journal of Management).

Pratama, A. (2018). Do Related Party Transactions and Tax Avoidance Affect Firm Value?. Review of Integrative Business and Economics Research, Vol.7, pp.106-116.

Ryngaert, M., and Thomas, S. (2012). Not All Related Party Transactions (RPTs) Are The Same: Ex ante versus Ex post RPTs. Journal of Accounting Research, Vol. 50 No.3, pp.845-882.

Schweizer, D., Walker, T., and Zhang, A. (2017). Cross-Border Acquisitions by Chinese Enterprises: The Benefits and Disadvantages of Political Connections. Journal of Corporate Finance, Vol.57, pp 63-85.

Shi, H., Xu, H., and Zhang, X. (2018). Do Politically Connected Independent Directors Create or Destroy Value?. Journal of Business Research, Vol.83, pp.82-96.

Shin, J.Y., Hyun, J. H., Oh, S., and Yang, H.(2018). The Effects of Politically Connected Outside Directors on Firm Performance: Evidence From Korean Chaebol Firms. Corporate Governance: An International Review, Vol.26 No.1, pp.23-44..

Srinivasan, P. (2013). An Analysis of Related-Party Transactions In India. IIM Bangalore Research Paper Working Paper No 402. Available at:

https://papers.ssrn.com/sol3/papers.cfm?abstract_id=2352791

Sutrisno, T., Saraswati, E. and Purnomosidhi, B. (2019). The Effect of Related Party Transactions on Firm Performance: The Moderating Role of Political Connection in Indonesian Banking. Business: Theory and Practice, Vol. 20, p.81.

Tambunan, M. E., Siregar, H., Manurung, A. H., and Priyarsono, D. S. (2017). Related Party Transactions and Firm Value in The Business Groups in The Indonesia Stock Exchange. Journal of Applied Finance and Banking, Vol.7 No.3, p.1.

Tsai, C. C., Chang, L. E., and Chang, Y. L. (2015). Related Party Transactions and Corporate Value. Journal of Economics, Business and Management, Vol.3 No.10, pp.924-928.

Utama, C. A., and Utama, S. (2014). Corporate Governance, Size and Disclosure of Related Party Transactions, and Firm Value: Indonesia Evidence. International Journal of Disclosure and Governance, Vol.11No.4, pp.341-365.

Wang, F., Xu, L., Zhang, J., and Shu, W. (2018). Political Connections, Internal Control and Firm Value: Evidence From China's Anti-Corruption Campaign. Journal of Business Research, Vol.86, pp.53-67.

Wang, L. (2015). Protection or Expropriation: Politically Connected Independent Directors in China. Journal of Banking \& Finance, Vol.55, pp.92-106.

Wang, S. (2016). Business Cycles, Political Connectedness, and Firm Performance in China. KDI School of Pub Policy \& Management Paper, (16-12). Available at SSRN: https://papers.ssrn.com/sol3/papers.cfm?abstract_id=2592348 
INTERNATIONAL JOURNAL OF ACADEMIC RESEARCH IN BUSINESS AND SOCIAL SCIENCES

Vol. 10, No. 9, 2020, E-ISSN: 2222-6990 @ 2020 HRMARS

Wong, W. Y., and Hooy, C. W. (2018). Do Types of Political Connection Affect Firm Performance Differently?. Pacific-Basin Finance Journal, Vol.51, pp.297-317.

Wu, H., Li, S., Ying, S. X., and Chen, X. (2018). Politically Connected CEOs, Firm Performance, and CEO Pay. Journal of Business Research, Vol.91, pp.169-180.

Wu, W., Wu, C., Zhou, C., and Wu, J. (2012). Political Connections, Tax Benefits and Firm Performance: Evidence from China. Journal of Accounting and Public policy, Vol.31 No.3,pp 277-300.

Yang, J., Lian, J., and Liu, X. (2012). Political Connections, Bank Loans and Firm Value. Nankai Business Review International, Vol. 3 No.4, pp.376-397.

Zhang, X. (2016). Value relevance of historical information and forecast information in China: Empirical evidence based on the Ohlson and Feltham-Ohlson models. Academy of Accounting and Financial Studies Journal, Vol.20 No.3, pp.14-27. 